\title{
Effects of Different Land Use Changes and Spatial Variation in Rainfall on Soil Properties and Soil Carbon Storage in Western Rajasthan, India
}

\author{
G. Singh* and Ritu Sharma \\ Division of Forest Ecology, Arid Forest Research Institute, New Pali Road, Jodhpur-342005 \\ *Email: gsingh@icfre.org
}

\begin{abstract}
Soil organic carbon (SOC) is an important indicator of both soil productivity and climate change mitigation. However, changes in land uses coupled with variability in air temperature, rainfall and frequent droughts affect SOC stock and hence people livelihoods. SOC was estimated by sampling soils in 0-30 cm soil layers from six dominant land use types like roadside, Oran (sacred groves), gauchar, agriculture land, forest and fallow land in 102 villages (10\% of total village) randomly selected from six panchayat samiti (blocks) namely Aburoad, Bali, Sanchor, Sankada, Bap and Baitu situated in Sirohi, Pali, Jalore, Jaisalmer, Jodhpur and Barmer district, respectively in Western Rajasthan. Rainfall (197.0- $689.5 \mathrm{~mm}$ annually), human (3.6- 11.5 person) and livestock (211 animals) population per household varied widely between the blocks and influenced soil gravel content (3.7- 40.6\%), bulk density $\left(1.2-1.8 \mathrm{~g} \mathrm{~cm}^{-3}\right)$ and SOC (0.06- 0.64\%) concentration. SOC stock varied $(\mathrm{P}<0.05)$ spatially between 0.66 tons $\mathrm{ha}^{-1}$ in Baitu and 16.33 tons ha ${ }^{-1}$ in Aburoad. Different blocks fell in order Baitu $<$ Sankara $<$ Bap $<$ Sanchor $<$ Bali $<$ Aburoad for soil carbon stock. About 1.63fold variations in SOC stock between highest (fallowland) and lowest (roadside) signified the importance of differing cultivation. SOC stock enhanced by increased rainfall and compost addition in farmland, but negatively affected by increased dune formation (sandy soils), soil gravel and stone fraction and increased livestock population per household. This indicates high potential of carbon sequestration through re-afforestation and restoration of these degraded lands by minimizing the negative factors.
\end{abstract}

Key words: Land use, carbon stock, rainfall, relationships.

\section{Introduction}

Soil-based carbon sequestration offers the possibility of large-scale removal of greenhouse gases from the atmosphere through plant photosynthesis and its conversion into soil organic carbon under decomposition of litter and root turnover. The carbon stored in the soils worldwide exceeds the amount of carbon stored in phytomass and the atmosphere [1]. The important strategy to reduce atmospheric carbon dioxide is to increase the global storage of carbon in soils, which has an added benefit of increased agricultural production [2]. In general, the surface soil layer has the highest level of SOC which decreases with depth down the soil profile [3-5]. The actual amount of SOC present in a soil depends on a number of factors like rainfall, air temperature, vegetations, soil types and its composition, topography, types of land uses, disturbances etc. [6-8], but individual efforts in this direction are more important in mitigating the effects of climate change [9].

Increasing SOC pool is a major challenge in dry areas, which are climatically harsh and crop productivity is limited by low availability of water and nutrients [10]. High population density, variable rainfall and increasing temperature together with natural resource devastation are promoting the process of land degradation and soil carbon loss [11]. The productivity of dry lands vegetation towards varying stresses and consequently soil carbon sequestration depends on a variety of factors like severity and duration of the stress, vegetation types and growth rates and variations in climatic and edaphic conditions [12-15]. Though there are policies and programmes at international, national and regional levels to curb the problems of desertification, land degradation and drought, problems remain the same. Increasing human population exponentially and livestock population by a power relation and corresponding anthropogenic activities further add to the problems of dry areas of Rajasthan, India [16, 
17]. Over grazing of village commons, vegetation removal for fodder and fuelwood, increased agricultural activities and in changing land uses for commercial crops altogether affects soil carbon storage [18-19]. At the same time there are needs to conserve the existing biological diversity and natural resources and enhance biomass productivity to maintain functional behaviour of the drylands ecosystem and enhance people livelihood [20-21]. Before going for any conservation strategies are requirement to assess the impact of increased human and livestock population and land uses on soil carbon storage along a spatial gradient in arid region of western Rajasthan.

The objectives of this study were: (i) to estimate soil carbon storage under the influence of different land uses, (ii) spatial variation in soil carbon stock and finding out relationships between soil carbon stock and changing rainfall and human and livestock populations. The ultimate objective was to find out factor affecting soil carbon storage for its effective management.

\section{$2 \quad$ Materials and Methods}

\subsection{Site Characteristics}

Study was carried out in six blocks namely Aburoad, Bali, Sanchor, Sankada, Bap and Baitu in Sirohi

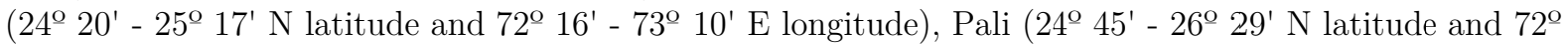
$47^{\prime}-74^{\mathrm{O}} 18^{\prime} \mathrm{E}$ longitude), Jalore $\left(24.48^{\mathrm{O}} 5^{\prime}-25.48^{\circ} 37^{\prime} \mathrm{N}\right.$ latitude and $71^{\mathrm{O}} 07^{\prime}-75.5^{\mathrm{O}} 53^{\prime}$ E longitude), Jaisalmer $\left(26^{\circ} 04^{\prime}-28^{\circ} 23^{\prime} \mathrm{N}\right.$ latitude and $69^{\circ} 20^{\prime}-72^{\circ} 42^{\prime} \mathrm{E}$ longitude), Jodhpur (26 $6^{\circ}-27^{\circ} 37^{\prime} \mathrm{N}$ latitude and $72^{\circ} 55^{\prime}-73^{\circ} 52^{\prime}$ E longitude) and Barmer $\left(24^{\circ} 58^{\prime}-26^{\circ} 32^{\prime} \mathrm{N}\right.$ Latitude and $70^{\circ} 05^{\prime}-72^{\circ} 52^{\prime}$ E Longitude) district, respectively in Western Rajasthan, India. Rainfall ranges from $197.0 \mathrm{~mm}$ in Bap area to $689.5 \mathrm{~mm}$ annually in Aburoad area. The area in Jodhpur, Jaisalmer and Barmer indicated lesser rainfall as compared to Jalore, Pali and Sirohi areas. During 1995 to 2014, lowest annual rainfall was in 2002 ranging from $48.5 \mathrm{~mm}$ in Sankada to $268.0 \mathrm{~mm}$ in Bali with an average value $118.60 \mathrm{~mm}$ (Fig 1). Average annual rainfall was highest $(711.4 \mathrm{~mm}$ ) in 2006, though it varied widely in the studied area. Average rainfall was highest in Bap in 2013, in Sankada and Sanchor in 2010 and in rest of the areas in 2006. When compared with overall average of $402.33 \mathrm{~mm}$ annually, 1995, 1996, 1998, 1999, 2000, 2001, 2002, 2004, 2005, 2008, 2009, 2012 and 2014 showed below average rainfall. In these there were increasing trend in rainfall during 1995 to 2014 except in Baitu block (Fig. 1a). Number of rain days ranged from 6-28 in Bap, 5-22 days in Sankarda, 9-22 in Bait, 7-37 in Sanchor, 14-43 in Bali, and 15-50 in Aburoad areas, with an average value of 14.8, 14.7, 14.5, 18.7, 24.9 and 31.4 rain-days in respective block. Lowest rainfall was in December (during 1995-2014) and highest in July. However, rainfall was greater in July in Abroad, Bali and Anchor, and in August in Bap, Sankada and Baitu areas (Fig. 1b).
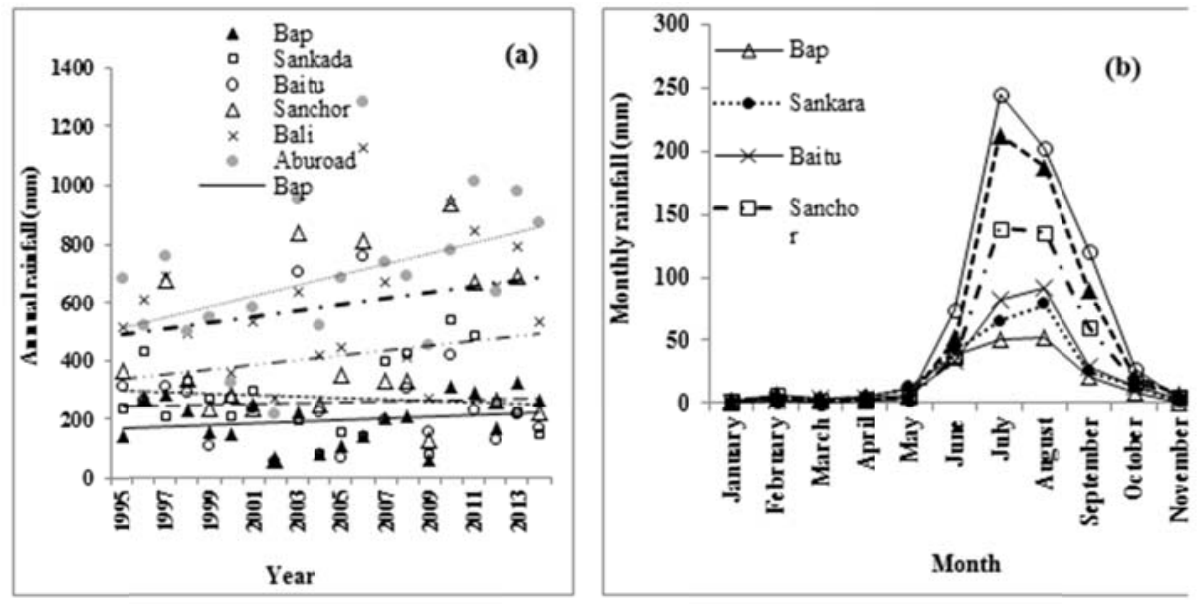

Figure 1. Change pattern in annual average rainfall during 1995 to 2014 (a) and monthly change in rainfall (b) in different blocks of in western Rajasthan.

There are extreme variations in the diurnal and annual temperatures in western Rajasthan. During 
the winter season it experiences very cold temperatures ranging from $-9^{\circ} \mathrm{C}$ to $30^{\circ} \mathrm{C}$. The lowest temperatures are recorded in January and begin to rise from March onwards and May and June are the hottest months when mean temperatures are above $40^{\circ} \mathrm{C}$. Individual day temperature reaches to the order of 47 to $51{ }^{\circ} \mathrm{C}$ occasionally. This region receives $>8 \mathrm{hrs}$ solar radiation per day on annual basis. It is 9 to 10 hours per day during summer, 4 to 7 hours per day after monsoon season and 10 hrs per day after withdrawal of monsoon (after October). Rajasthan receives solar radiation of about 6.0-7.0 $\mathrm{kWh}$ $\mathrm{m}^{-2}$ [22]. Because of low rainfall, about 325 days have good sunshine in a year, but in western areas in Thar Desert sunshine in a year may extend up to 345-355 days as rains occur only for 10.4-20.5 days in a year in the region [22]. Daily average wind speed ranges between 4.58 and $28.62 \mathrm{~km} \mathrm{hr}^{-1}$ with an average of $13.84 \mathrm{~km} \mathrm{hr}^{-1}$ at Jaisalmer, though it reaches up to $50-55 \mathrm{~km} \mathrm{hr}^{-1}$ during dust storms particularly during April - July months [23].

Soils of Sanchor and Baitu area are sandy in nature. Soils are very deep and sandy in nature, mostly associated with dunes, inter dunes and sandy plains in Baitu block, and sandy loam texture in Sanchor block [24]. Predominant texture of soil in Bap block is loamy sand with low silt and clay. Soils of Sankada block are sandy to sandy-loam in texture which are porous comprising of more of gravel and less silt and clay content. Soils texture in Bali areas is sandy loam to clay loam, whereas in Aburoad areas it is fine loamy to coarse loamy in nature. Most of the soils are slightly alkaline in reaction [24]. The floristic indicates poor forest resources in Jodhpur, Jaisalmer, Barmer and Jalor, but relatively better vegetations are observed in Pali and Sirohi districts. The sparse vegetation of former districts is categorized as 'Tropical thorn forest types, whereas in latter two districts it is categorized as 'Tropical dry deciduous forest types [25]. Desert districts are largely dominated by Israili babul (Acacia tortilis), khezri (Prosopis cineraria), ker (Capparis decidua), the bushes like Aak (Calotropis procera), Arni (Clerodendum phlomidides), Murali (Lycium barbarum), and the grasses like Shravan (Lasiurus sindicus), Dhaman (Cenchrus ciliaris) etc [26]. In Pali and Sirohi areas, the dominant species are Azadirachta indica, Acacia leucophloea, A. nilotica, A. tortilis, A. senegal, Anogeissus pendula, Bauhinia racemosa, Boswellia serrata, Salvadora persica, S. oleoides, Maytenus emarginata, Prosopis juliflora, Z. mauritiana, Aerva persica, Cassia auriculata, Calotropis procera, Leptadenia pyrotechnica, Ziziphus nummularia, Aristida adscensionis, A. funiculata, Crotalaria burhia, Indigofera cordifolia, Tephrosia purpurea, Heteropogon contortus, etc [5].

\subsection{Selection of Village and Land Use}

Total number of villages in this region range from 84 in Aburoad to 324 in Baitu with total 1024 villages in the region. Ten per cent of the villages, i.e 10, 32, 9, 14, 17 and 20 villages were selected randomly for soil sampling from Aburoad, Baitu, Bali, Bap, Sanchore and Sankara block respectively, making a total sum of one hundred two villages. These villages were considered as replicates in analysis work. Five major land uses in the region selected for soil sampling are agriculture, forests, Oran/sacred groves, pastureland and roadside. However, these five land uses are not available in all the villages. Therefore, depending upon the availability of land use types in the selected 102 number of villages soil sampling was done for carbon content analysis. In addition to these land uses, fallow lands other than the current fallows were also sampled as the control. Thus agriculture land was cropped area plus area under current fallow, forest land was forest lands or plantations, pastureland was grass lands plus culturable wasteland plus 'Parat' lands used for animal grazing, oran was a vegetated area set aside in name of some village deity and sacred in nature, roadside was area between road and agriculture or other lands and fallow land other than current fallows was areas left out of cultivation since more than five years.

\subsection{Human and Livestock Population}

Average family size (persons per households) varied from 3.6 in Sanchor to 11.5 in Sankada block with an average size of 5.6 in the studied areas (Table 1). It was relatively high as compared to the average family size normally taken to be four to five. Villages in Sankada, Bap and Bali blocks showed above average family size and were mostly dominated by either by tribal communities or by Muslim community. Average male and female individuals per household were 1.2 and 1.1 across the blocks. Number of children per household ranged from 1.9 in Sanchor to 7.1 in Sankada areas. Contribution of male, female and children to the total population was $20.6 \%, 20.4 \%$ and $59.0 \%$, respectively. Numbers of 
livestock per household varied from 2 in Sanchor to 11 in Sankada block with an average value of 4.3 animals per household (Table 1). In this, contributions of cow and goats were $22.1 \%$ and $63.5 \%$, respectively. Contribution of Buffalo, Ox, Sheep, Camel and Poultry was below $<8 \%$ with maximum share of Buffalo. While goat and sheep population has been observed high in Baitu and Sankada, the population of buffalo was greater in Sanchor, Aburoad and Bali blocks.

Table 1. Human population in the surveyed villages of different blocks of western Rajasthan.

\begin{tabular}{|c|c|c|c|c|c|c|c|c|c|}
\hline & \multirow{2}{*}{ Variable } & \multicolumn{6}{|c|}{ Block } & \multirow[b]{2}{*}{ Total } & \multirow[b]{2}{*}{$\%$} \\
\hline & & Baitu & Sankada & Baap & Sanchor & Aburoad & Bali & & \\
\hline \multicolumn{2}{|c|}{ House holds } & 537 & 220 & 146 & 847 & 329 & 270 & 2349 & \\
\hline \multirow{5}{*}{ 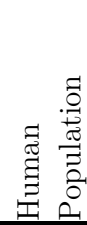 } & Male & 471 & 490 & 286 & 740 & 373 & 352 & 2712 & 20.6 \\
\hline & Female & 464 & 477 & 270 & 732 & 375 & 367 & 2685 & 20.4 \\
\hline & Children & 1460 & 1570 & 821 & 1602 & 1067 & 1237 & 7757 & 59 \\
\hline & Total Pop. & 2395 & 2537 & 1377 & 3074 & 1815 & 1956 & 13154 & 100 \\
\hline & $\mathrm{Av}$ per $\mathrm{HH}$ & 4.5 & 11.5 & 9.4 & 3.6 & 5.5 & 7.2 & 5.6 & \\
\hline \multirow{9}{*}{ 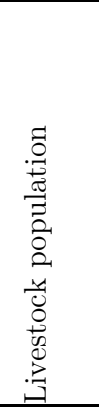 } & Cow & 367 & 434 & 450 & 436 & 176 & 386 & 2249 & 22.1 \\
\hline & Buffalo & 11 & 4 & 3 & 451 & 196 & 145 & 810 & 8 \\
\hline & $\mathrm{Ox}$ & 0 & 2 & 0 & 6 & 39 & 144 & 191 & 1.9 \\
\hline & Goat & 1839 & 1751 & 656 & 758 & 591 & 858 & 6453 & 63.5 \\
\hline & Sheep & 53 & 227 & 2 & 1 & 3 & 0 & 286 & 2.8 \\
\hline & Camel & 2 & 1 & 0 & 1 & 0 & 0 & 4 & 0 \\
\hline & Poultry & 0 & 0 & 0 & 0 & 4 & 169 & 173 & 1.7 \\
\hline & Total & 2272 & 2419 & 1111 & 1653 & 1009 & 1702 & 10166 & 100 \\
\hline & $\mathrm{Av}$ per $\mathrm{HH}$ & 4.2 & 11 & 7.6 & 2 & 3.1 & 6.3 & 4.3 & - \\
\hline
\end{tabular}

\subsection{Soil Sampling and SOC Estimation}

Soil samples were collected in top 0-30 $\mathrm{cm}$ soil layer in all five major land uses mentioned above by using mechanically driven iron auger for soil organic carbon estimation. For soil bulk density, soil samples were collected from each land use using a mechanically driven iron corer of fixed volume at 15 $\mathrm{cm}$ soil depth, transported to laboratory, oven dried at $110{ }^{\circ} \mathrm{C}$ and weighed [27]. Soil samples for carbon estimation were dried and passed through a $2 \mathrm{~mm}$ sieve for separation of gravel and fine earth fraction. Gravel fraction was calculated on weight/weight basis and used for correction in carbon stock calculation. Soil organic carbon (SOC) was determined from fine earth fraction $(<2 \mathrm{~mm}$ size) following standard procedures [28] by using potassium dichromate as the oxidant and ferrous ammonium sulphate as the reducing agent [29]. Soil organic carbon (SOC) stock was calculated using the following equation [30]:

$$
Q i=\text { CiDiEi }(1-G i) * 10000
$$

where Qi (tons or $\mathrm{Mg} \mathrm{C} \mathrm{ha-1)} \mathrm{is} \mathrm{soil} \mathrm{organic} \mathrm{carbon} \mathrm{content} \mathrm{in} \mathrm{a} \mathrm{soil} \mathrm{layer} \mathrm{i,} \mathrm{Ei} \mathrm{is} \mathrm{soil} \mathrm{depth} \mathrm{in} \mathrm{meters,} \mathrm{Ci}$ is carbon content in $\mathrm{g} \mathrm{C} \mathrm{g}^{-1}$ soil, Di is bulk density in $\mathrm{Mg} \mathrm{m}^{-3}$, and Gi is volume fraction of coarse (gravel or stones of $>2 \mathrm{~mm}$ size) elements.

\subsection{Statistical Analysis}

The data collected were statistically analyzed using SPSS statistical package version 8.0 for window 2000. Soil bulk density, gravel fraction, per cent soil organic carbon and soil carbon density were analyzed by two way ANOVA, where blocks in different districts and land uses were the fixed factors and number of villages were considered as the replicates. To obtain the relationships between different soil variables, rainfall and village human and livestock population, Pearson correlation was performed. Relationships between different soil variables, rainfall and village human and livestock were also developed. The least significant difference test was used to compare land uses as well as spatial variations at the $\mathrm{P}<0.05$ levels. 


\section{Results}

\subsection{Soil Physical Properties}

Average gravel content in soils across the blocks and land uses was $13.99 \%$, though it ranged from $<10 \%$ to even $>50 \%$ in the soil. It varied $(\mathrm{P}<0.05)$ both due to spatial distribution of blocks and land uses as well (Table 2). Soils of Sanchor and Baitu were sandy in nature with least gravel content. Soils of Bap and Sankada block were similar in gravel content but differed $(\mathrm{P}<0.05)$ with Sanchor and Baitu block as well as with Bali and Aburoad block (DMRT), which indicated highest gravel content. Among the land uses, lowest amount of gravel was in the soils of agriculture land, whereas it was highest $(\mathrm{P}<0.05)$ in forest lands, followed by gauchar land. Soils of agriculture land, roadside and fallow land did not differ in gravel content. Block $\times$ land use interaction term was non-significant $(\mathrm{P}>0.05)$. However, it was highest in forests of Aburoad and lowest in agriculture land of Sanchor block. Soil bulk density (BD) varied from $1.2 \mathrm{~g} \mathrm{~cm}^{-3}$ to $1.8 \mathrm{~g} \mathrm{~cm}^{-3}$ with an average value of $1.46 \mathrm{~g} \mathrm{~cm}^{-3}$ across the blocks and land uses. Variation was significant $(\mathrm{P}<0.05)$ both due to blocks as well as land uses (Table 2). Among the blocks, BD was lowest in Bali block and highest in Bap block. Soils of Baitu, Sanchor and Sankada blocks were almost similar $(\mathrm{P}>0.05)$ in $\mathrm{BD}$. While considering land uses across the block, $\mathrm{BD}$ was highest $(\mathrm{P}<0.05)$ in fallow land and was lowest in the soils along road side. Block $\times$ land use interactions was also significant $(\mathrm{P}<0.05)$ with highest BD in fallow-lands of Sankada and lowest in forest lands of Bali block (Table 2).

Table 2. Effects of spatial variations and land uses on soil gravel content, organic carbon. values are mean \pm SE of multiple replications.

\begin{tabular}{|c|c|c|c|c|c|c|c|c|c|c|}
\hline \multirow[t]{2}{*}{ Variables } & \multirow[t]{2}{*}{ Land use } & \multicolumn{7}{|c|}{ Blocks } & \multicolumn{2}{|c|}{ Two-way ANOVA } \\
\hline & & Bali & Baitu & Aburoad & Sanchor & Baap & Sankara & Mean* & Variable & F value \\
\hline \multirow{7}{*}{ 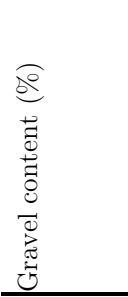 } & Forest & $45.6 \pm 5.40$ & $6.0 \pm 3.87$ & $51.7 \pm 2.10$ & $0.8 \pm 0.36$ & $3.7 \pm 2.05$ & $9.1 \pm 4.75$ & $23.9^{c}$ & Block & $44.57^{* *}$ \\
\hline & Oran & $40.2 \pm 10.7$ & $5.8 \pm 2.31$ & $38.6 \pm 6.25$ & $0.8 \pm 0.13$ & $17.0 \pm 9.40$ & $22.8 \pm 6.79$ & $20.9^{\mathrm{bc}}$ & $\mathrm{LU}$ & $2.50^{*}$ \\
\hline & Pastureland & $39.9 \pm 5.49$ & $4.7 \pm 1.85$ & $42.2 \pm 5.28$ & $3.3 \pm 2.23$ & $10.6 \pm 5.08$ & $11.2 \pm 5.74$ & $15.0^{\mathrm{ab}}$ & \multirow[t]{2}{*}{$\mathrm{B} \times \mathrm{LU}$} & NS \\
\hline & Agriculture & $31.4 \pm 3.93$ & $1.7 \pm 0.63$ & $36.4 \pm 3.82$ & $0.9 \pm 0.16$ & $8.8 \pm 3.05$ & $9.4 \pm 2.75$ & $10.1^{\mathrm{a}}$ & & \\
\hline & Roadside & $35.0 \pm 3.63$ & $4.6 \pm 0.90$ & $37.8 \pm 5.27$ & $4.7 \pm 2.58$ & $4.4 \pm 1.02$ & $4.8 \pm 1.48$ & $10.6^{\mathrm{a}}$ & & \\
\hline & Fallowland & $28.5 \pm 0.00$ & $0.6 \pm 0.00$ & $23.0 \pm 0.00$ & $1.8 \pm 0.00$ & $13.7 \pm 0.00$ & $4.7 \pm 0.00$ & $12.0^{\mathrm{a}}$ & & \\
\hline & Mean* & $37.9^{\mathrm{c}}$ & $3.7^{\mathrm{a}}$ & $40.6^{c}$ & $2.54^{\mathrm{a}}$ & $8.5^{\mathrm{b}}$ & $10.3^{\mathrm{b}}$ & & & \\
\hline \multirow{7}{*}{ 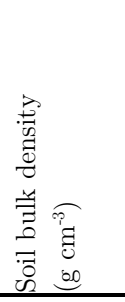 } & Forest & $1.32 \pm 0.02$ & $1.41 \pm 0.07$ & $1.45 \pm 0.02$ & $1.52 \pm 0.03$ & $1.55 \pm 0.01$ & $1.49 \pm 0.02$ & $1.45^{\mathrm{a}}$ & Block & $10.32^{* *}$ \\
\hline & Oran & $1.45 \pm 0.02$ & $1.47 \pm 0.03$ & $1.45 \pm 0.02$ & $1.47 \pm 0.03$ & $1.55 \pm 0.01$ & $1.48 \pm 0.02$ & $1.48^{\mathrm{a}}$ & $\mathrm{LU}$ & $4.14^{* *}$ \\
\hline & \begin{tabular}{|l|} 
Pastureland \\
\end{tabular} & $1.36 \pm 0.03$ & $1.47 \pm 0.02$ & $1.45 \pm 0.02$ & $1.50 \pm 0.01$ & $1.54 \pm 0.02$ & $1.51 \pm 0.02$ & $1.48^{\mathrm{a}}$ & \multirow[t]{2}{*}{$B \times L U$} & $1.94^{* *}$ \\
\hline & \begin{tabular}{|l} 
Agriculture \\
\end{tabular} & $1.38 \pm 0.04$ & $1.46 \pm 0.01$ & $1.42 \pm 0.02$ & $1.47 \pm 0.02$ & $1.51 \pm 0.02$ & $1.47 \pm 0.02$ & $1.46^{\mathrm{a}}$ & & \\
\hline & Roadside & $1.44 \pm 0.02$ & $1.46 \pm 0.01$ & $1.40 \pm 0.02$ & $1.43 \pm 0.02$ & $1.45 \pm 0.02$ & $1.47 \pm 0.01$ & $1.45^{\mathrm{a}}$ & & \\
\hline & Fallowland & $1.48 \pm 0.00$ & $1.50 \pm 0.00$ & $1.51 \pm 0.00$ & $1.56 \pm 0.00$ & $1.56 \pm 0.00$ & $1.58 \pm 0.00$ & $1.53^{\mathrm{b}}$ & & \\
\hline & Mean* & $1.39^{\mathrm{a}}$ & $1.46^{c}$ & $1.43^{\mathrm{b}}$ & $1.47^{\mathrm{c}}$ & $1.51^{\mathrm{d}}$ & $1.48^{\mathrm{c}}$ & & & \\
\hline \multirow{7}{*}{ 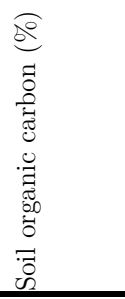 } & Forest & $0.53 \pm 0.08$ & $0.05 \pm 0.02$ & $0.70 \pm 0.07$ & $0.14 \pm 0.04$ & $0.12 \pm 0.02$ & $0.12 \pm 0.02$ & $0.33^{c}$ & Block & $60.36^{*}$ \\
\hline & Oran & $0.36 \pm 0.08$ & $0.05 \pm 0.01$ & $0.60 \pm 0.10$ & $0.16 \pm 0.02$ & $0.12 \pm 0.03$ & $0.15 \pm 0.01$ & $0.23^{\mathrm{ab}}$ & $\mathrm{LU}$ & $\mathrm{NS}$ \\
\hline & Pastureland & $0.41 \pm 0.11$ & $0.07 \pm 0.01$ & $0.63 \pm 0.06$ & $0.17 \pm 0.02$ & $0.12 \pm 0.01$ & $0.12 \pm 0.01$ & $0.22^{\mathrm{ab}}$ & \multirow[t]{2}{*}{$\mathrm{B} \times \mathrm{LU}$} & $\mathrm{NS}$ \\
\hline & \begin{tabular}{|l} 
Agriculture \\
\end{tabular} & $0.48 \pm 0.04$ & $0.09 \pm 0.01$ & $0.69 \pm 0.15$ & $0.22 \pm 0.03$ & $0.14 \pm 0.02$ & $0.12 \pm 0.01$ & $0.22^{\mathrm{ab}}$ & & \\
\hline & Roadside & $0.30 \pm 0.06$ & $0.04 \pm 0.01$ & $0.55 \pm 0.10$ & $0.21 \pm 0.04$ & $0.19 \pm 0.02$ & $0.13 \pm 0.02$ & $0.18^{\mathrm{a}}$ & & \\
\hline & Fallowland & $0.54 \pm 0.00$ & $0.06 \pm 0.00$ & $0.87 \pm 0.00$ & $0.12 \pm 0.00$ & $0.12 \pm 0.00$ & $0.06 \pm 0.00$ & $0.28^{\mathrm{bc}}$ & & \\
\hline & Mean* & $0.42^{\mathrm{d}}$ & $0.06^{\mathrm{a}}$ & $0.64^{\mathrm{e}}$ & $0.19^{c}$ & $0.14 \mathrm{~b}^{\mathrm{c}}$ & $0.13^{\mathrm{b}}$ & & & \\
\hline
\end{tabular}

B: block; LU: land use; NS: not significant at $\mathrm{P}<0.05$.

*Mean value with superscript of different alphabets in a row and column indicates significant difference for a particular soil variable between blocks and land use respectively. 


\subsection{Soil Organic Carbon}

Per cent soil organic carbon $(\mathrm{SOC})$ in top $0-30 \mathrm{~cm}$ soil layer varied $(\mathrm{P}<0.05)$ due to spatially distributed blocks (Table 2). It was highest Aburoad and lowest in the soils of Baitu block. Soils of Bap block did not differ $(\mathrm{P}>0.05)$ in SOC with both Sankada and Sanchor block. Among land uses, SOC did not differ, but DMRT indicated significantly $(\mathrm{P}<0.05)$ less $\mathrm{SOC}$ in pasture land. Soils of fallow land and forest lands were similar in SOC, though forest land had highest concentrations of SOC in general. Block x land use interactions term was not significant.

\subsection{Soil Carbon Stock}

Soil carbon stock in 0-30 $\mathrm{cm}$ soil layer was $7.12 \pm 0.33$ (mean $\pm 1 \mathrm{SE}$ ) tons $\mathrm{ha}^{-1}$ across the blocks and land uses. It varied $(\mathrm{P}<0.05)$ significantly between the blocks, whereas it approached $(\mathrm{P}=0.071)$ significant value for the land uses (Table 3). Lowest and highest values of soil carbon stock were in the soils of Baitu (2.66 tons ha $\mathrm{P}^{-1}$ ) and Aburaod (16.33 tons ha $\mathrm{a}^{-1}$ ) block, respectively. Soils of Bap and Sanchor were almost similar $(\mathrm{P}>0.05)$ in soil carbon stock. The order of block for soil carbon stock was: Baitu $<$ Sankada $<$ Bap $<$ Sanchor $<$ Bali $<$ Aburoad. While considering land uses (across the blocks), the lowest carbon stock $\left(6.17\right.$ tons ha $\left.{ }^{-1}\right)$ was in the soils along roadside, but it did not differ $(\mathrm{P}>0.05)$ with the carbon stock in the soils of Oran, gauchar, agriculture and forest lands. Highest (10.08 tons ha $\left.{ }^{-1}\right)$ amount of carbon stock was in fallow land. The order of land uses for soil carbon stock was: Roadside $<$ Oran $<$ gauchar $<$ agriculture land $<$ Forest $<$ Fallow land. Block $\times$ land use interaction was not significant $(\mathrm{P}>0.05)$, though the value of soil carbon stock was highest $\left(30.43\right.$ tons $\left.^{-1} \mathrm{~h}^{-1}\right)$ in fallow land of Aburoad and lowest (1.61 tons ha $\left.{ }^{-1}\right)$ in the soils along roadside of Baitu block.

Table 3. Effects of spatial variations and land uses on soil carbon stock (tons ha-1) after gravel correction. Values are mean $\pm 1 \mathrm{SE}$ of multiple replications.

\begin{tabular}{|c|c|c|c|c|c|c|c|}
\hline \multirow[t]{2}{*}{ Land use } & \multicolumn{6}{|l|}{$\overline{\text { Block }}$} & \multirow[b]{2}{*}{ Mean* } \\
\hline & Bali & Baitu & Aburoad & Sanchor & Baap & Sankada & \\
\hline Forest & $11.16 \pm 1.69$ & $1.85 \pm 0.76$ & $14.42 \pm 1.12$ & $6.18 \pm 2.12$ & $5.17 \pm 0.81$ & $4.86 \pm 0.67$ & $8.27^{\mathrm{ab}}$ \\
\hline Oran & $8.97 \pm 2.38$ & $2.16 \pm 0.45$ & $16.13 \pm 3.19$ & $6.82 \pm 0.96$ & $4.56 \pm 0.94$ & $5.02 \pm 0.51$ & $6.98^{\mathrm{a}}$ \\
\hline Pastureland & $10.47 \pm 3.43$ & $2.9 \pm 0.52$ & $16.71 \pm 3.27$ & $7.45 \pm 0.93$ & $5.09 \pm 0.58$ & $4.72 \pm 0.59$ & $7.06^{\mathrm{a}}$ \\
\hline Agriculture & $13.91 \pm 1.72$ & $3.77 \pm 0.29$ & $18.63 \pm 4.43$ & $9.6 \pm 1.00$ & $5.68 \pm 0.75$ & $4.65 \pm 0.26$ & $7.53^{\mathrm{ab}}$ \\
\hline Roadside & $8.47 \pm 2.01$ & $1.61 \pm 0.29$ & $14.22 \pm 2.43$ & $8.4 \pm 1.52$ & $7.87 \pm 0.7$ & $5.38 \pm 0.68$ & $6.16^{\mathrm{a}}$ \\
\hline Fallowland & $14.26 \pm 0.00$ & $2.69 \pm 0.00$ & $30.43 \pm 0.00$ & $5.51 \pm 0.00$ & $4.83 \pm 0.00$ & $2.70 \pm 0.00$ & $10.08^{\mathrm{b}}$ \\
\hline Mean* & $10.85^{\mathrm{d}}$ & $2.66^{\mathrm{a}}$ & $16.39^{\mathrm{e}}$ & $8.15^{\mathrm{c}}$ & $5.95^{\mathrm{b}}$ & $4.92^{\mathrm{b}}$ & \\
\hline \multicolumn{2}{|c|}{ Two-way ANOVA } & $\mathrm{F}$ value & $\mathrm{P}$ value & & & & \\
\hline \multicolumn{2}{|l|}{ Block } & 34.95 & 0.000 & & & & \\
\hline \multicolumn{2}{|l|}{ Land use } & 2.95 & 0.071 & & & & \\
\hline \multicolumn{2}{|c|}{ Block $\times$ land use } & 1.02 & 0.444 & & & & \\
\hline
\end{tabular}

*Mean value with superscript of different alphabets in a row and column indicates significant difference for a particular soil variable between blocks and land use respectively.

\subsection{Relationship among Different Variables}

Spatial variation in annual average rainfall showed positive correlation with gravel content, per cent SOC and soil carbon stock and human and livestock populations (Table 4). However, rainfall was negatively correlated with soil bulk density and number of animals per household (cow, goat and sheep). Per cent soil organic carbon and carbon stock both were negatively correlated to soil bulk density and to livestock per household, but had positive correlations to human populations. Soil bulk density showed a decreasing trend with increase in rainfall (Fig 2a). However, rainfall observed related to SOC concentration $\left(\mathrm{R}^{2}=0.618, \mathrm{P}<0.001\right)$ and soil organic carbon stock $\left(\mathrm{F}_{2 / 359}=127.6, \mathrm{R}^{2}=0.415, \mathrm{SE}=5.09\right.$, $\mathrm{P}<0.001)$ by quadratic relationships (Fig 2). Soil carbon stock followed a logarithmic decreasing trend $\left(\mathrm{F}_{1 / 360}=15.08, \mathrm{R}^{2}=0.04, \mathrm{SE}=6.22, \mathrm{P}<0.001\right)$ with increase in number of livestock per household (Fig 
3). The decrease in SOC stock was more significant with increased population of goat $\left(\mathrm{F}_{1 / 360}=20.65\right.$, $\mathrm{P}<0.001)$.

Table 4. Correlations in different variables of soils and socio-economic profile of a village in the studied area.

\begin{tabular}{l|l|l|l|l|l|l|l}
\hline Variable & Gravel & \%SOC & BD & CSW & CSG & Rainfall & HHs \\
\hline Gravel & - & $0.578^{* *}$ & $-0.252^{* *}$ & $0.574^{* *}$ & $0.321^{* *}$ & $0.660^{* *}$ & $0.208^{* *}$ \\
\hline \%SOC & $0.578^{* *}$ & - & $-0.297^{* *}$ & $0 / 997^{* *}$ & $0.926^{* *}$ & $0.745^{* *}$ & $0.160^{*}$ \\
\hline Soil bulk density & $-0.252^{* *}$ & $-0297^{* *}$ & - & $-0.243^{* *}$ & $-0.195^{* *}$ & $-0.365^{* *}$ & $-0.153^{* *}$ \\
\hline Rainfall & $0.660^{* *}$ & $0.745^{* *}$ & $-0.365^{* *}$ & $0.740^{* *}$ & $0.626^{* *}$ & - & $0.342^{* *}$ \\
\hline Population & $0.187^{* *}$ & $0.129^{*}$ & $-0.133^{*}$ & $0.118^{*}$ & $0.117^{*}$ & $0.338^{* *}$ & $0.984^{* *}$ \\
\hline Pop./HHs & $0.129^{*}$ & 0.100 & - & 0.100 & - & - & - \\
\hline Livestock & $0.225^{* *}$ & - & $-0.170^{* *}$ & - & - & $0.241^{* *}$ & $0.874^{* *}$ \\
\hline LS/HHS & - & $-0.144^{* *}$ & - & $-0.148^{*}$ & $-0.181^{*}$ & $-0.174^{* *}$ & $-0.247^{* *}$ \\
\hline Cow & - & $-0.129^{*}$ & - & $-0.128^{*}$ & $-0.114^{*}$ & $-0.245^{* *}$ & $-0.186^{* *}$ \\
\hline Buffalo & $0.179^{*}$ & $0.362^{* *}$ & $-0.126^{*}$ & $0.364^{* *}$ & $0.395^{* *}$ & $0.579^{* *}$ & $0.217^{* *}$ \\
\hline Ox & $0.548^{* *}$ & $0.435^{* *}$ & $-0.427^{* *}$ & $0.410^{* *}$ & $0.315^{* *}$ & $0.599^{* *}$ & $0.458^{* *}$ \\
\hline Goat & $-0.105^{*}$ & $-0.198^{* *}$ & - & $-0.201^{* *}$ & $-0.233^{* *}$ & $-0.238^{* *}$ & $-0.262^{* *}$ \\
\hline Seep & - & $-0.126^{*}$ & - & $-0.125^{* *}$ & $-0.123^{*}$ & $-0.167^{* *}$ & - \\
\hline
\end{tabular}

*: significant at $\mathrm{P}<0.05 ; * *$ : significant at $\mathrm{P}<0.01$.
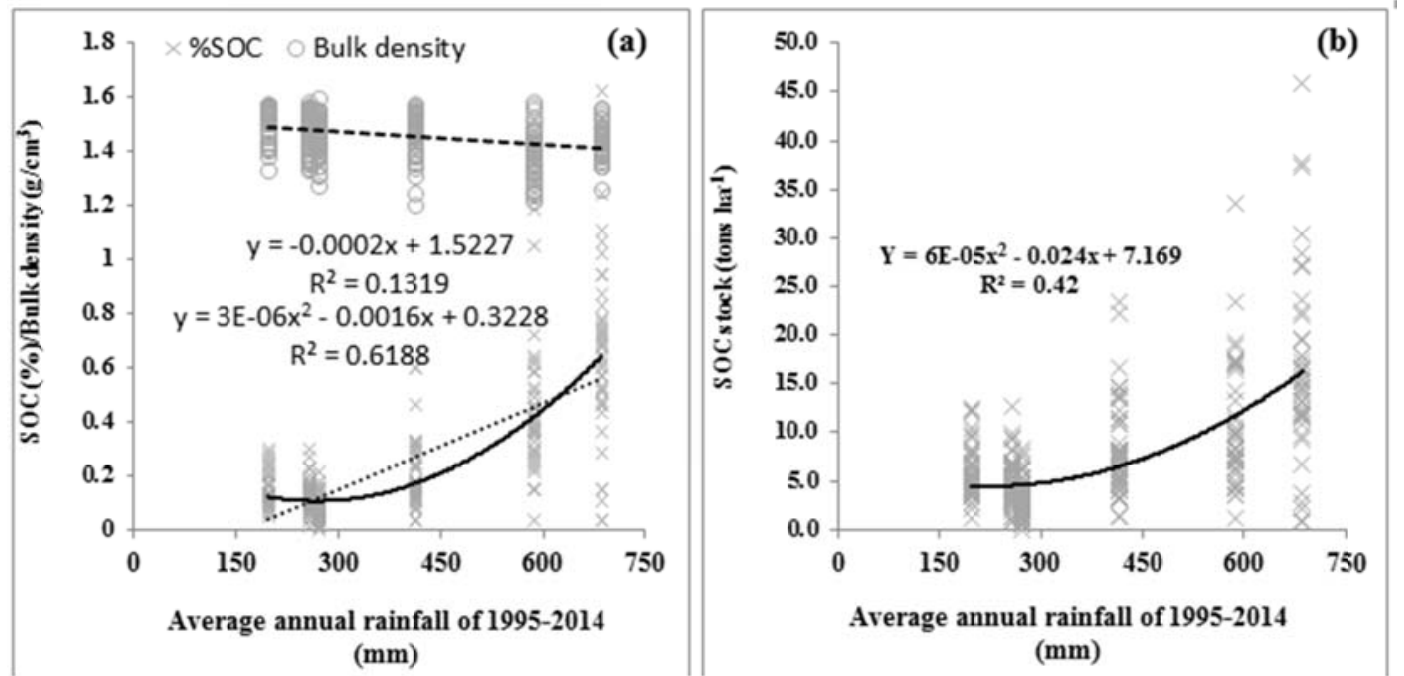

Figure 2. Trend line relationships of rainfall with soil organic carbon and soil bulk density (a) and soil carbon stock with and without gravel correction (b).

\section{Discussion}

Lowest soil bulk density in Bali and Aburoad was due to increased SOC and rainfall as well that favour soil organic matter accumulation through increased vegetation cover and corresponding litter addition. It was also indicated by positive relationships between SOC content and annual rainfall $\left(\mathrm{F}_{2 / 359}=291.3\right.$, $\left.\mathrm{R}^{2}=0.618, \mathrm{P}<0.001\right)$. Beneficial effects of rainfall are through increased soil water availability favouring vegetation growth and biomass production and subsequently soil organic carbon enrichment. Sustaining carbon uptake however, relies on growth and development of vegetation, which rerquires careful balance with biomass removal through grazing or harvesting affecting carbon sequestration [31, 32]. Significant variations in SOC between land uses were due to combined effects of climatic and anthropogenic factors [33]. Liu et al [34] observed significant regional impact of rainfall, temperature, elevation, clay and silt 
contents and land use on soil carbon density. However, a negative impact of human activities was also recorded on SOC accumulation [34] as observed in present study. However, negative correlation of SOC concentration with soil bulk density and animals per households indicates that villages with smaller number of households had greater number of domestic animals particularly small ruminants affecting SOC content and SOC stock probably through overgrazing and trampling (Fig 3). Positive effect of buffalo population $(\mathrm{r}=0.362, \mathrm{P}<0.01)$ on increased SOC stock was due to stall feeding particularly in area with increased water availability and application of its manure to farmlands for increasing farm productivity [35].

Carbon stored in soils is affected by changes in vegetation and plant growth, removal of biomass by harvest, mechanical soil disturbances and environmental changes like global warming or nitrogen deposition [36]. However, land use changes had significant influences on soil carbon stocks. Lowest carbon stock in grazing lands (gauchar) indicated dominant impacts of trampling by livestock during grazing as compared to the chemical and biological impact of faeces and urine added to soils by animals affecting soil carbon status in pasture land and roadside [37, 38]. This was also supported by negative relationship between livestock population per household and SOC stock (Figure 3). However, greater amount of soil carbon storage in 'Oran' as compared to the other community lands appeared to be due to woody vegetation growing in the area under community conservation [39]. Higher estimate of SOC stock in fallow land followed by agriculture lands of Aburoad/Bali block appeared to be due to conserved organic matter and added farm yard manure. The changes in the order of block and land uses for the soil carbon stock were due to gravel content. However, relatively greater soil carbon stock in fallow land suggests the benefit of leaving farmlands as fallow to recoup the SOC and nutrients. Continuous cultivation of agriculture land exposed the soil for oxidation leading to decrease in SOC as compared to fallow land. However, higher SOC stock in the topsoil $(0-10 \mathrm{~cm})$ of grazing land has also been reported as compared to forest soil and cultivated soil [40]. The higher content of gravel and stone in forest soil resulted in a lower estimate of the SOC stock per unit area despite of similar SOC contents in forest and grazing lands.

Almost 25-fold variation in SOC stock between Baitu (0.66 tons ha-1) and Aburoad (16.33 tons ha h $\left.^{-1}\right)$ blocks indicated strong spatial differences in soil carbon storage influenced by climatic and edaphic factors $[41,42]$. Though rainfall was significantly related to soil carbon stock $\left(\mathrm{F}_{2 / 359}=127.6, \mathrm{R}^{2}=0.415\right.$, $\mathrm{SE}=5.09, \mathrm{P}<0.001)$, soil types also played an important role on SOC. It was indicated by low SOC in Baitu block dominated by sandy nature of the soils and was similar to the observation recorded in Ajmer district of Rajasthan where soils with clay texture were higher in organic carbon than soils having textures of loamy sand and sand soils [43]. It was also indicated by relatively greater amount of soil carbon stock in Sankada and Bap blocks with relatively heavy in soil texture despite of low average annual rainfall as compared to Baitu block showing the role of soil type and texture on soil carbon storage [44].
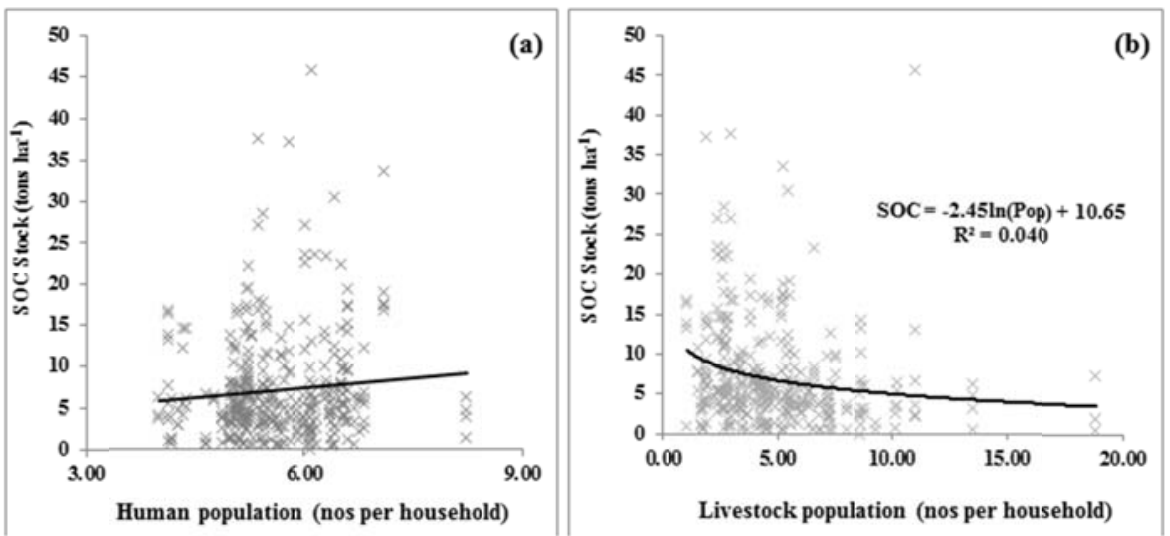

Figure 3. Relationships of soil organic carbon stock with human (a) and livestock (b) population per household. 


\section{Conclusion and Recommendations}

Changes in land uses coupled with variability in climatic and edaphic factors affected soil carbon storage in western Rajasthan. Spatial variations in rainfall in different blocks (districts) along with livestock population and soil characteristics (texture) affected soil bulk density and SOC concentrations causing 25-fold variations in SOC storage between Baitu and Aburoad blocks. Highest amount of SOC in fallowland emphasizes the importance of reduced cultivation on soil carbon storage, but lowest SOC stock along roadside indicates the effects of enhanced anthropogenic activities. Increased rainfall and corresponding soil water availability and organic manuring in farmland favoured SOC stock, but soil loss and increased content of gravel and stone fraction in soil and increased livestock population per household played a negative role in soil carbon accumulation. Reducing the negative factors, promoting vegetation cover, organic manuring of farmlands and restoration of degraded lands may enhance soil carbon storage with increased productivity of these degraded lands.

Acknowledgements. We wish to express our sincere thank to the Director Arid Forest Research Institute, Jodhpur for providing facilities to conduct out research. We are also grateful for financial assistance provided by Mitigating Poverty in Western Rajasthan (MPOWER) to carry out this work.

\section{References}

1. J. P. W. Schalemann, E. V. J. Tanner, R. Heiderer and V. Kapos, "Global soil carbon: understanding and managing the largest terrestrial carbon pool." Carbon Management, vol. 5, no. 1, pp. 81-91, 2014.

2. C. Epple, S. García Rangel, M. Jenkins, and M. Guth, "Managing ecosystems in the context of climate change mitigation: a review of current knowledge and recommendations to support ecosystem-based mitigation actions that look beyond terrestrial forests". Technical Series No.86. Secretariat of the Convention on Biological Diversity, Montreal, 55 pages, 2016.

3. A. J. Franzluebbers and J. A. Stuedemann, "Soil-profile organic carbon and total nitrogen during 12 years of pasture management in the Southern Piedmont USA." Agriculture, Ecosystems and Environment, doi:10.1016/j.agee.2008.06.013), 2008.

4. G. Singh, S. Mutha and N. Bala, "Growth and productivity of Prosopis cineraria based agroforestry system at varying spacing regimes in the arid zone of India." Journal of Arid environment, vol. 70 no. 1, pp. 152-163, 2007.

5. G. Singh, "Studies on carbon sequestration in different forest types of Rajasthan." A project report of AFRI, Jodhpur submitted to ICFRE, Dehradun, India, 2014.

6. W.W. Emerson, "Water retention, organic carbon and soil texture." Australian Journal of Soil Research, vol. 33, pp. 241-251, 1995.

7. G. Singh, "Effects of rainwater harvesting devices in controlling runoff losses and enhancing productivity in Aravalli ranges". Project report AFRI Jodhpur submitted to ICFRE, Dehradun, 2011.

8. E.U. Hobley and B. Wilson, "The depth distribution of organic carbon in the soils of eastern Australia." Ecosphere, vol. 7, no. 1, pages 21, www.esajournals.org, 2016.

9. H. T. Pandey, P.S. Chawala, K. Fernandez, S. A. Singru, D. Khismatrao and S. Pawar, "Assessment of awareness regarding climate change in an urban community." Indian Journal of Occupational and Environmental Medicine, vol. 15, no. 3, pp. 109-112, 2011.

10.R. Lal, "Sequestering carbon in soils of arid ecosystems." Land Degradation \& Development, vol. 20, no. 4, pp. 441-454, 2009.

11.N. J. McKenzie, J. A. Baldock, M. R. Balks, A. M. Camps, L. M. Condron, M. Elder-Ratutokarua, M. J. Grundy, A., Hewitt, F. Kelliher, J. F. Leys, R. W. McDowell, R. J. Morrison and N. R. Schoknecht, "Regional assessment of soil change in the Southwest Pacific. Status of the World's Soil Resources (SWSR) - Main Report, 2015, pp. 476-519, Rome, Italy: FAO and ITPS.

12.V. Chaplot, B. Bouahom and C. Velentin, "Soil organic carbon stocks in Laos: spatial variations and controlling factors. Global Change Biology, vol. 16, no. 4, pp. 1380-1393, 2010. 
13.L. Galiano, J. Martínez-Vilalta and F. Lloret, "Drought-induced multifactor decline of Scots Pine in the Pyrenees and potential vegetation change by the expansion of co-occurring oak species." Ecosystems (NY), vol. 13, no. 7, pp. 978-991, 2010..

14.S. M. Vicente-Serrano, A. Zouber, T. Lasanta and Y. Pueyo, "Dryness is accelerating degradation of vulnerable shrublands in semiarid Mediterranean environments." Ecological Monograph, vol. 82, no. 4, pp. 407-428, 2012.

15.G. Singh, "Sacred groves of Rajasthan: threats and management strategies." Scientific Publisher (India), Jodhpur. 2016, p. 295.

16.G. Singh, B. Singh, U.K. Tomar and S. Sharma, "A Manual for dryland Afforestation and Management. Scientific Publisher (India), 2017, Jodhpur, p. 605.

17.G. Singh, " Studies on the effects of mpower programme on mitigation and adaptation towards climate change in western Rajasthan. A project report of AFRI, Jodhpur submitted to MPOWER, Jodhpur (Rajasthan), India.

18.R. Xie and X. J. Wu, "Effects of grazing intensity on soil organic carbon of rangelands in Xilin Gol League, Inner Mongolia, China." Journal of Geographical Sciences, vol. 26, pp. 1550-1560, 2016.

19.J. Sun, T. E. Twine, J., Hill, R. Noe, J. Shi and M. Li, "Effects of Land Use Change for Crops on Water and Carbon Budgets in the Midwest USA." Sustainability, vol. 9, doi:10.3390/su9020225, 2017.

20.J. P. Gupta, D. C. Joshi, D.C. and G. B. Singh, "Management of Arid Agro-ecosystem". In Natural Resource Management for Agricultural Production in India, J.S.P. Yadav and G.B. Singh (Eds.), pp.551-668. International Conference on Managing Natural Resources for Sustainable Agricultural Production in the 21st Century hold on Feb. 14-18, 2000, New Delhi, India.

21.S.K, Dhyani, K. Kareemulla, Ajit and A. K. Handa, "Agroforestry potential and scope for development across agro-climatic zones in India." Indian Journal of Forestry, vol. 32, pp. 181-190, 2009.

22.R.S. Meena, D. Sharma and R. Rathore, "The most promising solar hot spots in India development and policy: the Thar Desert of Rajasthan." International Journal of Engineering and Developmental Research, vol. 3, no. 1, pp. 74-79, 2014.

23.P. Santra, R. S. Mertia, R. N. Kumawat H. R. Mahla, "Loss of soil carbon and nitrogen through wind erosion in the Indian Thar Desert." Agricultural Physics, vol. 13, pp. 13-21, 2013.

24.R. L. Shyampura and J. Sehgal, "Soils of Rajasthan for Optimising Land Use. NBSS Publ., Soils of India Series. National Bureau of Soil Survey and Land Use Planning, Nagpur, lndia: 76 + 6, 1999.

25.H. G. Champion and S. K. Seth, "A revised survey of the forest types of India." Delhi: Manager of Publications, 1968.

26.K. Singh, "Effect of land use types on floral diversity and carbon stock in Jodhpur district of Rajasthan." Theses submitted to FRI University, Dehradun for award of Ph. D. degree, 2015.

27.D. S. McIntyre and J. Loveday, "Bulk Density", In Methods for analysis of 18 irrigated soils. Tech. Comm. No 54, J. Loveday (Ed), pp. 38-42, 1975. Bureau of Soils, Commonwealth Agricultural Bureau, Farnham 19 Royal, England.

28.A. Walkley and I. A. Black, "An examination of the Degtiareff method for determining soil organic matter and proposed modification of the chromic acid titration method." Soil Science, vol. 63, pp. 29-38, 1934.

29.IPCC, "IPCC Report on Good Practice Guidance for Land Use, Land-Use Change and Forestry. 2007, p. 204.

30.N. H. Batjes, "Total carbon and nitrogen in the soils of the world." European Journal of Soil Science, vol. 47, no. 2, pp. 151-163, 1996.

31.J. D. Derner and G.E. Schuman, "Carbon sequestration and rangelands: A synthesis of land management and precipitation effects. Journal of Soil and Water Conservation. vol. 62, pp. 77-85, 2007.

32.M. L. Thomey, P. L. Ford, M. C. Reeves, D. M. Finch, M. E. Litvak and S. L. Collins, "Review of climate change impacts on future carbon stores and management of warm deserts of the United States." General Technical Report. RMRS-GTR-316. Fort Collins, CO: U.S. Department of Agriculture, Forest Service, Rocky Mountain Research Station, p. 26, 2014.

33.D. M. K. Amara, S. A. Koroma, P. J. Kamanda, A. M. Kamara and D. H. Saidu, "Effects of land use on Soil organic carbon fractions in soils of Njala Landscape in Sierra Leone. International Journal of Environment, Agriculture and Biotechnology, vol. 1, no. 4, pp. 637-645, 2016.

34.Z. Liu, M. Shao and Y. Wang, "Effect of environmental factors on regional soil organic carbon stocks across the Loess Plateau region, China. Agriculture, Ecosystem and Environment, vol. 142, pp. 184-194, 2011. 
35.P. T. Ngo, C. Rumpel, T. D. Thu, T. H. des-Tureaux, D. K. Dang and P. Jouquet, "Use of organic substrates for increasing soil organic matter quality and carbon sequestration of tropical degraded soil: a 3-year mesocosms experiment." Carbon Management, vol. 5, no. 2, pp. 155-168, 2014.

36.I. A. Janssens, W. Dieleman, S. Luyssaert, J. A. Subke, M. Reich-stein, R. Ceulemans, P. Ciais, A. J. Dolman, J. Grace, G. Matteucci, D. Papale, S. L. Piao, E. D. Schulze, J. Tang and B.E. Law, "Reduction of forest soil respiration in response to nitrogen deposition.", Natural Geosciences, vol. 3, pp. 315-322, 2010.

37.A. P. Whitmore, "Impact of livestock on Soil. Available: http://agriculture.de/acms1/conf6/ws4lives.htm.

38.M. A. Liebig, J. R. Gross, S. L. Kronberg,, R. L. Phillips and J. D. Hanson, "Grazing management contributions to net global warming potential: A long-term evaluation in the Northern Great Plains. Journal of Environmental Quality, vol. 39, pp. 799-809, 2010.

39.S. Daryanto, D. J. Eldridge and H.L. Throop, "Managing semi-arid woodlands for carbon storage: Grazing and shrub effects on above- and belowground carbon." Agriculture, Ecosystems \& Environment, vol. 169, pp. 1-11, 2013.

40.B.M. Shrestha, B. K. Sitaula, B. R. Singh and R. M. Bajracharya, "Soil organic carbon stocks in soil aggregates under different land use systems in Nepal." Nutrient Cycling in Agroecosystems, vol. 70, pp. 201-213, 2004.

41.M. Von Lutzow and I. Kogel-Knabner, "Temperature sensitivity of soil organic matter decomposition-what do we know?" Biology and Fertility of Soils, vol. 46, pp. 1-15, 2009.

42.P. York, "The Environmental Impacts of Intensive Livestock Operations in Canada. Available: http://scienceforpeace.ca/the-environmental-impacts-of-intensive-livestock-operations-in-canada.

43.J. D. Giri, S. K. Singh, R. S. Singh and R. L. Shyampura, "Carbon stock and its distribution in soils of Ajmer district and management strategies for carbon sequestration." Agropedology, vol. 18, no. 1, pp. 21-32, 2007.

44.K. Venkanna, U. K. Mandal, U.K., A. J. S. Raju, K. L. Sharma, R. V.,Adake, Pushpanjali, B.S. Reddy, R.N. Masane, K. Venkatravamma and B. P. Babu, "Carbon stocks in major soil types and land-use systems in semiarid tropical region of southern India." Current Science, vol. 106, 604-611, 2014. 